\title{
The Use of Gold Dinar and Silver Dirham in Moslem Countries in the Contemporary Era
}

\author{
Muchammad Ichsan
}

\section{DATA NASKAH}

Masuk: 28 Desember 2016

Diterima: 17 April 2017

Terbit: 1 Juni 2017

KORESPONDEN PENULIS: Universitas Muhammadiyah Yogyakarta

Jalan Lingkar Selatan Tamantiro Kasihan Bantul Yogyakarta,

Email: drichsan65@yahoo.com

\section{ABSTRAK}

Dominasi dolar AS dan mata uang negara-negara maju lainnya, dan fakta bahwa mata uang mereka telah tertinggal, telah mendesak kelompok-kelompok Muslim di beberapa negara untuk menyeru menggunakan dinar emas dan dirham perak sebagai alat tukar. Penelitian ini bertujuan untuk mengkaji kebutuhan, aplikasi, dan hukum menggunakan dinar emas dan dirham perak dari perspektif Islam. Untuk mencapai tujuan yang ditetapkan pada saat ini, metode deskriptif digunakan dalam menulisnya dan metode analisa digunakan untuk menyimak masalah yang relevan. Studi ini menemukan bahwa dalam situasi saat ini kaum muslimin perlu menggunakan dinar emas dan dirham perak untuk kontrak keuangan mereka. Penggunaan dinar emas dan dirham perak ini bisa diberlakukan di era moden ini walaupun ada beberapa kendala dan masalah. Terakhir, penggunaan dinar emas dan dirham perak sebagai alat tukar dibenarkan menurut perspektif Islam berdasarkan beberapa dalil.

Kata Kunci: Dinar, Dirham, Muslim, Negara, Kontemporer

\section{ABSTRACT}

The dominance of the US dollar and other developed countries' currencies, as well as the fact that their currencies have fallen behind, have urged groups of Moslems in some countries to call for the use of gold dinar and silver dirham as a medium of exchange. This paper aims at examining the need, application, and law on the use of gold dinar and silver dirham from the Islamic perspective. To reach the goal set at this moment, a descriptive method is employed in the writing while an analytical method is used to scrutinize the relevant problems. This study finds that in the current situation Moslems need to use gold dinar and silver dirham for their financial contracts. The use of gold dinar and silver dirham is applicable in this modern era although there are some obstacles and problems. Lastly, the use of gold dinar and silver dirham as a medium of exchange is allowed 


\section{MEDIA
HUKUM}

from the Islamic perspective based on some propositions. Keywords: Dinar, Dirham, Moslem, Country, Contemporary.

\section{INTRODUCTION}

Gold and silver currency has been used as a medium of exchange by humans since thousands of years ago. And in the history of Islam, gold dinar and silver dirham have been adopted and employed as an official currency by Moslems in all corners of the world for very long since the time of Prophet Muhammad (PBUH). Sadly today, however, no Moslem countries use it. Every country now has a currency based on fiat or token money. Although some Moslem countries still use the name 'dinar' or 'dirham' as an official currency, they do not base it on gold and silver.

This situation has urged a group of Moslems in some countries like South Africa, Singapore, Malaysia, and Indonesia to apply gold dinar and silver dirham as an official currency in their respective country. They have begun to promote and encourage the use of gold dinar and silver dirham as what once happened in the history of Islam and Moslems. The primary factor driving this aspiration is their love for Prophet Muhammad (PBUH) and the successive Caliphs who used gold dinar and silver dirham. History shows the use of gold dinar and silver dirham at the time did not cause any problems. On the contrary, economic stability was maintained, and prosperity achieved.

Another factor is the fact the value of their currencies fall irregularly from time to time as they are not based on gold and silver. This is what we call inflation. Inflation is a state where the value of a currency diminishes compared to the prices of goods as the amount of money in circulation grows excessively, causing goods prices to rise. Such an event has accompanied token money since its birth, and it will always go with it forever.

Besides, Fiat or token money currently used as an official currency by people in all countries is problematic as it is generally based on the US dollar. In this state, the American economy will affect that of those other countries and make them dependent on the US dollar. Furthermore, by relying on fiat or token money the hegemony and dominance of the US dollar and other developed countries' currencies would never be matched, let alone overtaken, by Moslem nations, which are developing countries.

All this is interesting to study when there is a strong will to adopt gold dinar and silver dirham currency in Moslemmajority countries, specifically Indonesia. This research tries to answer the following questions: How much is the need of Moslems for using gold dinar and silver dirham as a medium of exchange and a means of a transaction? Can gold dinar and silver dirham be used as an official currency of a country in this modern era and if so what are the obstacles and problems? Lastly, what is the legality of using gold dinar and silver dirham as a medium of exchange from the perspective of Islamic law?.

\section{DISCUSSION}

\section{Moslems' Need for Gold Dinar and Silver Dirham}

Money in traditional economics is defined as a commonly accepted medium of exchange. This medium of exchange can be any object that is accepted by every member of the community in goods and service transactions. In modern economics, money is defined as something available and commonly accepted as a medium of exchange for the purchase of goods and services and other valuable assets and the payment of debts. The need of Moslems across the world to bring back the use of gold dinar and silver dirham as a currency has become increasingly urgent. The following points show the current situations of Moslems as well as the benefits of using gold dinar and silver dirham:

First, unifying Moslems. If now Moslems are divided into small countries and cannot be united politically, the reapplication of gold dinar and silver dirham may bring those countries together regarding the monetary system, without having to disturb each country's political conditions (Vadillo, no year, point: 3.2.1.3). European countries have been ahead in establishing a common currency in euro, so it is more than appropriate for Moslems to have a common currency in dinar and dirham based on gold and silver.

Secondly, making people prosperous. By using gold dinar and silver dirham as a medium of exchange and as a store of wealth, Moslems' prosperity in many countries will improve. In fact, it is not only Moslems that can be well-off 
with the application of gold dinar and silver dirham, but all people who use them. This is because gold dinar and silver dirham are universal in nature and have been proven throughout history as being unaffected by inflation and deflation. As a proof, a lamb at the time of the Prophet (PBUH) was priced at one dinar. One dinar was one coin of 22-carat gold weighing 4.25 grams. Today a lamb of similar quality remains at one dinar. This means the value of gold has not been affected by economic changes for over 14 centuries. (Sanhu, 2012: 12-13). If compared to the price of a goat in rupiah, ten years ago one of good quality can be purchased at Rp400,000, but now it is Rp1,700,000. In only ten years, the price of a goat has increased four times over. In other words, in a decade the value of the rupiah has decreased more than four-fold.

Thirdly, freeing from the banking interest system. If gold dinar and silver dirham are applied as an official currency, this can free Moslems from the interest system used in banking. Many ulemas have agreed that such interests are a form of riba (usury), which is forbidden by Allah and His Prophet. This is because gold and silver are unaffected by the banking system that is always prone to crises. The interest system can also never be applied to gold and silver as it is to paper money. Somehow, such interest system has caused the amount of money in circulation to grow with the increasing need for money. There is a simple formula that we can use to find out why paper money is prone to value reduction.

$M T=M o(1+i) n$

Where:

MT = Total money or the total amount of money after a period.

Mo = Initial money or the amount of money at the beginning.

$\mathrm{i}=$ Interest rate.

$\mathrm{n}$ = Amount of time (in a year). (Dipraja, 2011: 32-33. Apriyanti, no year: 56).

Fourthly, freeing from the dependence on the US dollar. By using gold dinar and silver dinar again, Moslems will be able to free themselves from the dependence on the US dollar with all its effects. On the contrary, as long as Moslems use the US dollar as a standard, a means of exchange, and a store of value, they will depend on the US dollar and let their economy be influenced and dominated by it. Therefore, a monetary crisis happening in the US will certainly affect all countries recognizing the US dollar. (Ari, 2013: 16-17). Lately many have predicted that a lot of countries will forsake the US dollar due to crises happening in the US itself. (Dipraja, 2011: 30).

Fifthly, it is fairer to all, especially developing countries. The use of gold dinar and silver dirham would be more appropriate for everyone especially Moslems who live in developing countries. This is because gold dinar and silver dirham are the real universal money. They are commonly recognized, and the physical forms have been valued across the world since a long time ago, while fiat money is only valuable in the country where it is made or recognized, and in a period of time.

Furthermore, by using gold dinar and silver dirham, Moslems will return to the practice of the Prophet (PBUH) and the Caliphs after him. In addition, there are many Islamic laws determined with gold and silver such as the smallest amount of assets (nisab) subject to the zakat, the minimum value of a brideprice, the fine (kaffara) for a man having sex with his wife while she is in a period, the minimum amount of stolen assets of which thief's hand must be cut, the Islamic blood money payment (diyya), the Islamic tax (jizya), and others. (Al-Iraqi, 2013: 6-7). Even in the Quran, the subject of the use of gold dinar and silver dirham is touched in numerous verses, such as sura AzZukhruf: 71, sura al-Insan: 15-16, sura at-Taubah: 34-35, sura Yusuf 19-20, sura al-Kahf: 19, sura Ali Imran: 75, and sura Ali Imran: 91.

Finally, the need for bringing back gold dinar and silver dirham as Moslems' official currency is more evident if we know the characteristics of paper money now used everywhere. Paper money is money created by humans to replace gold and silver. Many people know that it is in itself not valuable. Paper money is valid based on the laws of an issuing state (legal tender act), so the state's citizens must use it based on the provisions of the laws and those violating them will be subject to punishment. Therefore, paper money is not the real money, but it is a state's note of guarantee. The value assigned to a piece of paper money is 


\section{MEDIA
HUKUM}

higher than that of its physical paper materials, and this is unfair. The nominal value is often misunderstood as the intrinsic value and, what is worst, its value always decreases. This is called inflation. Inflation occurs when the amount of paper money in the market grows and so people's buying power weakens although the nominal value printed on the papers are still the same. If the value of money goes down, many people will unfairly suffer because they have to use a larger amount of paper money to purchase the same goods (Anonymous, no year: 8).

Besides, fiat or paper money is created as a primary instrument to ensure that the debt-based economic system involving usury works well. Without fiat money, this whole system will be ruined (Asatizah al-Munawwarah, 2013: 63). Economist Michael Maloney says that what is called money by people around the world is a momentary means of exchange (currency). Currency can never be able to serve as a store of value. To be so, something must be monetizable (can be converted into cash). Money, however, must have two functions, i.e. as a store of value and as a means of exchange. So, money can also be called currency, but currency does not necessarily take a form of money. And, according to Michael, only gold and silver have those characteristics. Since a long time ago, gold has been used as a store of value and as a means of exchange (Dipraja, 2011: 36-37).

\section{The Use of Gold Dinar and Silver Dirham and Its Problems.}

If the use of gold dinar and silver dirham as Moslems' official currency were applicable and did happen, then today in this modern age it would be possible as well as long as all parties have a strong will for it. History has even shown that the use of dinar and dirham was fortunate and advantageous. The benefits of gold dinar and silver dirham are visible. But the goodwill to re-adopt gold dinar and silver dirham in this modern era is surely not free from problems and challenges. Among them are as follows:

Firstly, there are still many Moslems, and especially their governments, who do not or not yet want it. In other words, until now there has not been a political will to use gold dinar and silver dirham again. There are many reasons for why they do not yet want the re-application of gold dinar and silver dirham, such as the lack of understanding and awareness of the benefits of gold dinar and silver dirham. Besides, moving from one economic system to another is not an easy thing to do as people are used to their previous system. Furthermore, many people still think that what was good in the past is not necessarily applicable today. The evidence: no Islamic countries-let alone non-Islamic oneshave gold dinar and silver dirham as their official currency.

Secondly, the laws applicable in countries where Moslems are majority have not allowed the use of gold dinar and silver dirham. In fact, the laws embrace and approve a currency not based on the gold and silver standard. The use of the rupiah in Indonesia, for instance, is regulated by Law No. 7 of 2011 on Currency. To amend this law is not an easy matter. It would take a long time and in-depth studies by experts in economy and law and the legislative body.

Moslems now have a currency in their respective country that is based on fiat or paper money. They have to use that currency as a medium of exchange, a standard of value, and a store of wealth as instructed by the laws. But this is unacceptable in the Islamic law. The reason is such laws prevent the use of gold dinar and silver dirham, which has been justified by Allah. Allah commands: "O you who have believed, do not prohibit the good things which Allah has made lawful to you and did not transgress. Indeed, Allah does not like transgressors" (QS Al-Maidah: 87). Another reason, we are compelled to accept something that worths more than its actual value. Also, we have to accept such currency, whether we like it or not (Vadillo, 2006: 61-62).

Thirdly, America and other Western countries would not like it if Moslems use gold dinar and silver dirham. That would overthrow their dominance, and their economy would be heavily shaken, and finally, their prosperity would be terribly impaired. Therefore, they would not stay still in this case. All efforts would be made to prevent, hamper, and fail the attempt to bring back gold dinar and silver dirham as Moslems' official currency (Kurniawan, 2012: 116-117). The Western economic system has grabbed a hold on Moslems' economy worldwide. It would not be easy for them to free themselves from that hold, as it is already too loud and deeply rooted, covering all aspects of 
the economy.

Lastly, gold and silver are mined materials, and so they are limited in amount. If all Moslems across the world readopt gold dinar and silver dirham as their official currency, the need for gold and silver will soar highly while the reserves of gold and silver are limited and even decreasing. Moreover, the mining of gold and silver is difficult, not as easy and cheap as printing paper money. Because of the limited amount, some big mining companies even state that they have begun to find it hard to look for new gold reserve locations. Also, the depth they are required to reach to find gold can be down to four kilometers with a temperature of 130 degrees Fahrenheit. It is not easy either to obtain the license from the relevant government, thus prolonging the time needed from mining to production. These challenges make the cost for gold explorations even higher (Ari, 2013: 8). According to Newmont, a gold mining company, the cost of drilling 1 ounce of gold equals to 500 US dollars (Dipraja, 2011: 12), . While the costs for printing US dollar notes according to the report by the Bureau of Engraving and Printing under the US Departement of the Treasury in its 2012 budget are as follows:

USD $\$ 1.00$ and USD $\$ 2.00$ cost 5.2 cents per sheet. USD $\$ 5.00$ and USD $\$ 10.00$ cost 8.5 cents per sheet.

USD $\$ 20.00$ and USD $\$ 50.00$ cost 9.2 cents per sheet.

USD $\$ 100.00$ costs 7.7 cents per sheet. (Anonymous, no year: 14)

Despite the many problems and challenges ahead, if there are a correct understanding and a strong will those obstacles can be overcome and the use of gold dinar and silver dirham, God willing, can be realized. The benefits for Moslems in this era and the next, however, are undeniable as explained above.

\section{The View of the Islamic Law on the Use of}

\section{Gold Dinar and Silver Dirham.}

So how does the Islamic law see the use of gold dinar and silver dirham as a medium of exchange, a unit of account, and a store of value? In this case, the jumhur (the majority of ulemas) is of the opinion that using dinar and dirham as Moslems' currency is legal and the law is mubah or permitted (Al-Iraqi, 2013: 22-27).

The propositions they rely on to allow the use of gold dinar and silver dirham as Moslems' currency are several Quranic verses, hadiths, and ijma' (the consensus of the Moslem community). The Quranic propositions come in the following verses:

1. "To them will be passed round, dishes and goblets of gold: there will be there all that the souls could desire, all that their eyes could delight in: and ye shall abide therein (for eye)" (QS Az-Zukhruf: 71)

2. "And amongst them will be passed round vessels of silver and goblets of crystal, crystal-clear, made of silver: they will determine the measure thereof (according to their wishes)" (QS al-Insan: 15-16).

The above verses show the afterlife reality about the use of gold and silver goblets which is forbidden by Allah in this world through the words of the Prophet (PBUH): "Those who drink with goblets made of gold or silver, will seethe in their stomach the fire of Jahannam" (narrated by al-Bukhari and Moslem). This prohibition is caused not by vanity but due to the use of gold and silver other than the real purposes of their creations. These two mines were created for humans to be an instrument of payment and as a standard of value.

3. "Fair in the eyes of men is the love of things they covet: women and sons; heaped-up hoards of gold and silver; horses branded (for blood and excellence); and (wealth of) cattle and well-tilled land. Such are the possessions of this world's life, but in nearness to Allah is the best of the goals (to return to)." (QS Ali Imran: 14).

This verse shows that Allah created within men a fitrah (true nature) to love women, children, and wealth. The first element is the underlying cause for the existence of families as the basis of human society. The second element, the love for wealth, is the basis of financial transactions and the driver of trade and economy. The most valued wealth is gold and silver. This means the love for them is human nature so that any community annulling or prohibiting transactions using the two mined objects is considered to have gone astray from its true nature. The Prophet (PBUH) illustrates humans' love for gold through his words: "If a child of Adam has 
one valley of gold, he will like it more to have two" (narrated by al-Bukhari).

4. "And there are those who bury gold and silver and spend it not in the way of Allah. Announce unto them a most grievous penalty on the day when heat will be produced out of that (wealth). In the Fire of Hell, and with it will be branded their foreheads, their flanks, and their backs - 'This is the (treasure) which ye buried for yourselves: taste ye, then, the (treasures) ye buried!" (QS at-Taubah: 34-35). The ulemas have provided reasons why in the above verse gold and silver are mentioned specifically instead of other assets subject to the zakat: Firstly, gold and silver can be hoarded, unlike other goods. Secondly, they are the first created instruments of payment. If they are hoarded, it will cause the stop of transactions and the loss of a standard of value in exchange.

5. "So they concealed him as a treasure! But Allah knoweth well all that they do! The (Brethren) sold him for a miserable price, for a few dirhams counted out: in such low estimation did they hold him!" (QS Yusuf 19-20).

6. "Such (being their state), we raised them up (from that they might question each other. Said one of them, "How long have ye (here)?" They said, "We have stayed (Perhaps) a day, or part of a day." length). They (all) said, "(Allah) (alone) knows best how long ye have stayed now send ye then one of you with this money of yours to the town: let find out which is the best food (to be had) and bring some to you, that ye satisfy your hunger therewith: and let him behave with care and courtesy, let him not inform anyone about you" (QS Al-Kahf: 19).

Allah states silver as a medium of exchange in the first and second verses above. In the second verse, silver is said to have a characteristic, which is its capability of storing value without being affected by time. Gold and silver can indeed serve to store value forever, and this makes both of them suitable for use as a medium of exchange and a standard of value, and as the only currency that can realize one of the objectives of the Islamic law, i.e. hifdzul maal (maintaining assets). This goal will never come to reality with paper money for it lacks the above characteristics as it is not intrinsically valuable, prone to inflation, and affected by political dynamics and the game played by those in control of the currency.

7. "Among the people of the Book are some who, if entrusted with a hoard of gold, will (readily) pay it back. Others, who, if entrusted with a single silver coin, will not repay it unless thou constantly stood demanding. Because, they say, "There is no call on us (to keep faith) with these ignorant (Pagans)." But they tell a lie against Allah, and (well) they know it" (QS Ali Imran: 75).

8. "As to those who reject Faith, and die rejecting,- never would be accepted from any such as much gold as the earth contains, though they should offer it for ransom. for such is (in store) a penalty grievous, and they will find no helpers" (QS Ali Imran: 91).

The two verses above show the legality of gold as an instrument to satisfy contracts. The second verse explains that matter by stating that the most awkward position for humans is that of the unbelievers on the Judgment Day when they would wish they could redeem themselves with their most loved asset, i.e. gold. This clearly shows that gold is a legal instrument to pay a ransom, and this will not happen if gold is not a legal instrument of payment.

From all the above verses, we can make the following statements that gold and silver are currency created by Allah to be an instrument of payment for goods and a standard of value for services. Allah created a fitrah (true nature) within man to love these two mines. Gold and silver are two means of exchange that are syar'i (legal and in line with the Islamic law). Gold and silver have unique physical characteristics and material value that make them suitable for storing value without affected by time. Gold and silver can serve as a standard of value. Gold and silver are two legal instruments for fulfilling obligations.

As for the hadith propositions, they are as follows: As told by Urwah al-Bariqi "that the Prophet (PBUH) gave him a dinar to buy a sacrificial animal or a sheep. He bought two sheep, sold one of them for a dinar, and brought him a lamb and dinar. So he invoked a blessing on him in his business dealing, and he was such that had he bought dust he would have made a profit from it" (narrated by alBukhari). Besides, the Prophet (PBUH) also made/established several laws related to gold dinar and silver dirham, such as 
the laws on riba, zakat, diyyat, and others.

As for the ijma' proposition, it has been declared that the use of a gold and silver-based currency for Moslems is legal.

\section{CONCLUSION}

Gold and silver have been commercially used in society for thousands of years, and both have been adopted and employed by Moslems since the times of the Prophet (PBUH) and later the successive Caliphs.p The need to put gold dinar and silver dirham back into service as a currency for Moslems is becoming more pressing for the sake of their unity and prosperity. So, that they could avoid dependence on and the dominance of the US dollar that always involves inflation and interests, which is a form of usury forbidden by Allah. Gold dinar and silver dirham can be made Moslems' official currency if there is a strong will from all relevant parties despite some obstacles and challenges. The use of gold dinar and silver dirham according to the Islamic law is allowed because it has benefits or virtues for Moslems. It is time for Moslems to understand and be aware of the advantages and the importance of reviving gold dinar and silver dirham.

The following are some suggestions based on the above conclusion: Firstly, efforts are needed to spread the information on the benefits and advantages of gold dinar and silver dirham to improve Moslems and their leaders' understanding, awareness, and will be related to the matter. Such efforts can be made, among others, using lectures and writings in the mass media both print and electronic, through education at school and especially in higher education, and through workshops, and seminars.p And to achieve this objective, there needs to be an individual body or institution that will be responsible for it. Secondly, Moslems need to start using gold dinar and silver dirham in their religious services and commercial transactions - even though in a limited scope - without waiting for the approval of the respective government. Thirdly, Moslem communities need to convincingly persuade their respective government to adopt gold dinar and silver dirham as an official currency so that the authority will accept it because they need it, not due to compulsion or exhortation. Fourthly, steps towards amending laws that prevent the use of gold dinar and silver dirham need to be taken although it would take a long time and require in-depth studies. Finally, Moslems need to ensure the adequacy of gold and silver materials to make dinar and dirham by exploring new gold and silver mines, buying and importing them from other countries, and conducting international trade using gold and silver.

\section{BIBLIOGRAPHY}

Al-Iraqi, Ali, 2013, Al-Takyiif al-Fiqhi li al-Nizaam alNaqdi al-Haali, (Paris: Al-Ma'had al-Aurubi li al-Ulum al-Insaniyah - al-Kulliyyah al-Aurubiyyah li al-Dirasat al-Islamiyyah, unpublished paper).

Anonymous, no year, Fatwa Mengenai Wang Kertas, (unpublished paper).

Apriyanti, Maya, no year, Anti Rugi Dengan Berinvestasi Emas, (Yogyakarta: Pustaka Baru Press).

Ari, Yustina, 2013, Investasi Emas Untuk Ibu Rumah Tangga, (Yogyakarta: Suaka Media).

Asatizah al-Munawwarah, 2013, Hujjah Terang Benderang Untuk Mengembalikan Wang Suci Kita, (No place of publication and name of publisher).

Dipraja, Sholeh, 2011, Siapa Bilang Investasi Emas Butuh Modal Gede?, (Jakarta: PT. Tangga Pustaka). Kurniawan, Endy J., 2012, Think Dinar!, (Depok: AsmaNadia Publishing House).

Sanhu, Andreas, 2012, Membeli Emas Perhiasan, (Yogyakarta: Lukita).

Vadillo, Shaykh Umar Ibrahim, no year, Muamalat: The Alternative to the Riba System Exists, (unpublished paper).

\section{Websites:}

Vadillo, Umar Ibrahim, 2006, Fatwa On Banking, retrieved from http://zakat.files.wordpress.com/ 2006/11/fatwaonbanking.pdf, on May 10, 2017, at $11.00 \mathrm{am}$. 